Halyna Bryikhanova, Ph.D. $\mathrm{PhD}$ (Pedagogics), Associate Professor of Department of Journalism and Advertising Kyiv National University of Trade and Economics, Kyiv Google Scholar https://scholar.google.com.ua/citations?user=Di6q8ZoAAAAJ\&hl=en; ORCID: 0000-0002-1664-8990; ResearcherID: Q-2771-2018

Olexandr Liezhniev, Senior lecturer of Department of Journalism and Advertising Kyiv National University of Trade and Economics, Kyiv Google Scholar https://scholar.google.com/citations?user=6Sn5ZrYAAAAJ\&hl=ru; ORCID: 0000-0003-1549-996X;

\title{
BRANDING OF TOURIST ZONES AS THE DEVELOPMENT OF ACTUAL TERRITORIAL POSSIBILITIES
}

At the present stage of development of the Ukrainian economy, the question of becoming brands of tourist destinations, which play a significant role in the positioning and promotion of goods and services in the tourist services market, is relevant. Considering the fact that even cities today are fighting for the share of consumers, tourists, investors, it becomes obvious the need for a successful branding of territories beyond their borders. Nowadays the world's leading countries use area branding technology to manage their perception of the country. This allows us to move towards building a positive image not only of cities, but also of the state as a whole, purposefully influencing public opinion.

Keywords: brand, tourist's place, destination, consumers, marketing, territory, image.

The relevance of this article is due to the fact that an insufficient number of strong Ukrainian tourism brands. That is the reason of study and development of the theoretical foundations of branding technology in the field of tourism, the development of appropriate organizational mechanisms and methods for their practical implementation in the conditions of the respective firms and organizations that make up the tourism business infrastructure (including advertising agencies and consulting firms). 
The aim of this work is to consider and study the theoretical and methodological aspects of organizing branding as a technology for promoting the tourism business.

Formulation of the problem. The concepts of «brand», «branding» and «brand manager» have appeared in the Ukrainian marketing vocabulary relatively recently. The reaction to these new terms for the domestic market is mixed even among leading marketers, and even more so among practicing entrepreneurs. Thus, in general terms, branding refers to the joint creative activity of the advertiser and the advertising agency to create and widely introduce into the consumer's mind a «personified image disguised by a certain trademark».

In the domestic market, especially consumer goods and products, the brands of foreign companies are leading, actively penetrating our market. Many leaders of Ukrainian companies, paying tribute to their capabilities, are at the same time afraid of the arrival of large Western companies and their absorption of domestic brands. These fears are justified, since forecasting and planning at enterprises, ideas about the economic situation and trends at the level of macro- and microeconomics, etc. do not correspond to the real situation and the requirements of modern technologies.

Analysis of recent research and publications. Proponents of a modern approach to the development of brand-oriented business models see branding as a strategic tool for generating company profits that stimulates the development of media technologies and new business models with different approaches to creating brands.

Currently, brand management is the focus of many experts. Problems of branding formation are devoted to the research works of a considerable number of foreign scientists and practitioners M. Abellan, S. Anholt, N. Hollis, G. Bekvit. In Ukraine and other countries of the post-socialist space branding problems are devoted to the works of O. Milashovska, O. Kurban S. Trukhimovich, I. Rozhkov, M. Dymshits, summarize the experience of leading companies in the world in gaining strong competitive positions in the global and Ukrainian tourism markets as a result of branding.

Presenting main material. A brand, as a product, at the same time satisfies various expectations and preferences of consumers at four levels of quality:

- the functional quality of the brand (purpose) is based on the ability of the product underlying the brand to fulfill its purpose in accordance with corporate, national and international standards;

- individual brand quality (value) is expressed in the brand's ability to match consumers' life values;

- the social quality of the brand (respect) provides consumers with membership in a social group, allows them to receive social recognition and approval;

- the communicative quality of the brand (promise) is based on its ability to maintain relationships with consumers, summarizing all the characteristics of functional, individual and social quality and offering special benefits to the consumer. 
Having appeared on the market, the brand develops throughout the entire life cycle, transforming the essence of the brand from the totality of identifying elements (brand name, brand name, style, slogan) to consumers clearly perceived values as a combination of functional and emotional elements that are common with the goods and the way it is presented.

The consistent development of the brand from simple awareness to the formation of loyalty is provided by branding.

In the setting of constant growth of competition under equal conditions managing marketing of any territory, such marketing categories as brand and image have important value when comparing geographical areas located in almost identical business conditions. In this regard, more and more countries and cities are purposefully engaged promotion of their territories and the formation of their own brand, which determine the tourist attractiveness of the area [2].

Currently, in any region in order to develop tourism, there is a development of a complex of various marketing events, among which the formation of a positive attitude towards the region and its recognition - territorial branding - is becoming increasingly popular. Positioning a positive image of the region, which should be unique, is becoming a prerequisite for the development of a branded tourist area.

When developing a brand concept for a tourist territory, in our opinion, it is necessary to be guided by the following key points:

1. The formation of the basic principles of tourism development territory and brand management.

2. Identification of the initial mission of the region in the field of tourism.

3 . The definition of the main resource values of tourism territory.

4. Identification of the main consumer groups of the brand [3].

As part of the work on creating a branding concept of the region as a tourist territory, first of all, the existing brands of the territory, brands of individual tourism products and regions, as well as tourist centers are studied. Then the general communication elements that are used or can be used in the process of branding the territory are revealed.

As a result of the study of brands, recommendations are made regarding the existing brands of the region as a tourist territory, as well as recommendations for their improvement, reorientation and repositioning to develop a concept for a new brand in case of its absence.

The process of creating a branding concept of the region as a tourist territory in order to increase its tourist attractiveness is a system of sequential work and events, which can be represented in the form of the following scheme (figure). 


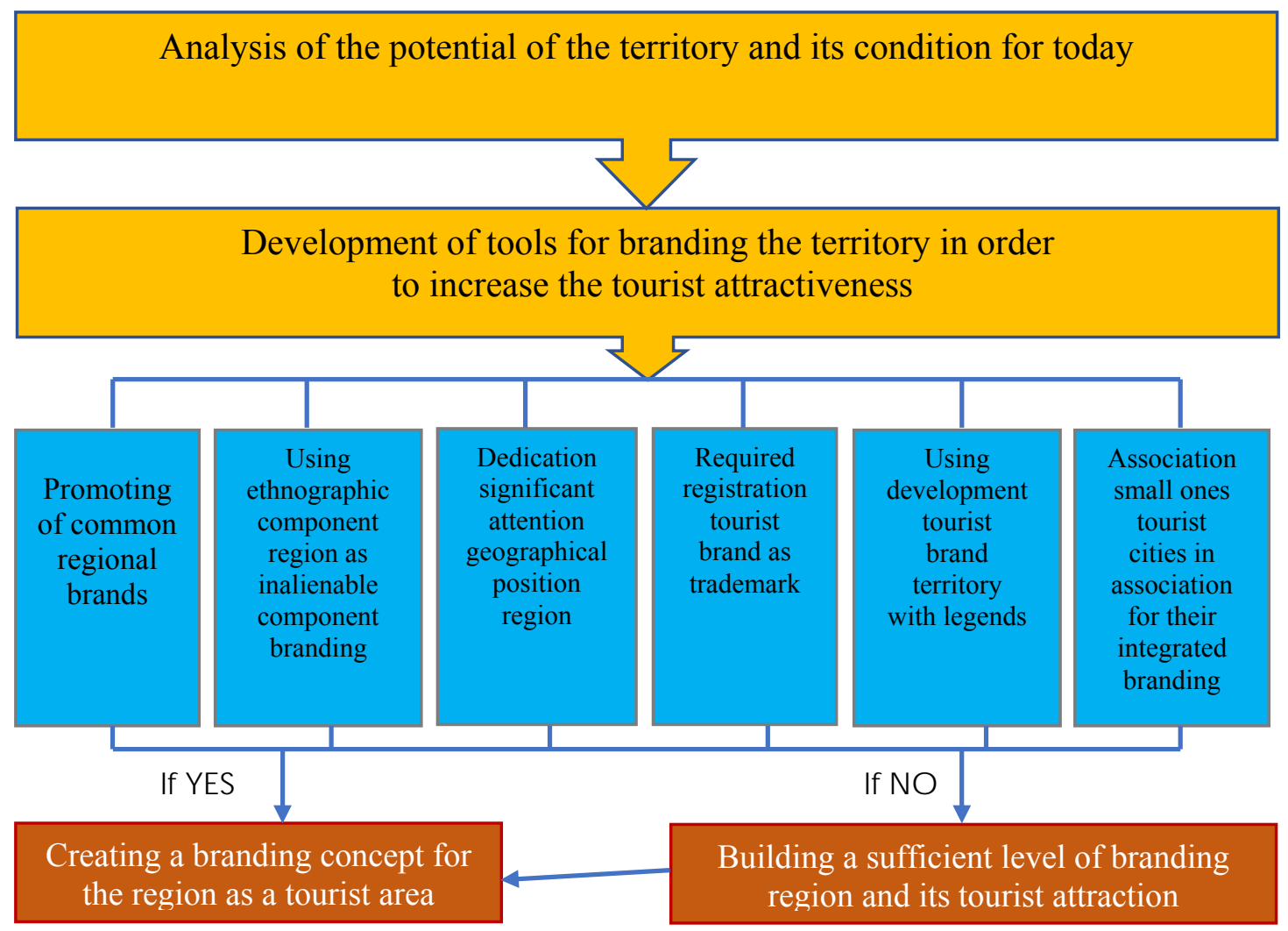

Fig. 1. A model for creating a branding concept of the region as a tourist territory in order to increase its tourist attractiveness

Source: Created by authors

In addition, it should be noted that when creating the branding concept of the region as a tourist territory, reflected in this model, the following principles should be guided:

1. The possibility of using the concept at the international level.

2. Clarity and ease of sharing information.

3. Full and accurate brand perception by potential consumers.

4. Strengthening the competitiveness of the region through branding by isolating it from existing ones.

Based on the above, we can offer the following program for branding a region to increase its tourist attractiveness:

1. The choice of tourist territory subject to branding.

2. Identification of persons interested in branding the territory.

3. SWOT analysis of the branding region in order to identify external opportunities and threats, as well as strengths and weaknesses.

4. Analysis of the tourist potential of the region and assessment of its current state.

5. Setting goals and objectives of branding the territory.

6. Designing innovative activities in order to promote the region and increase its tourist attractiveness. 
7. Development of a branding program for the territory.

8. Obtaining regional support from a special territory branding management service.

9. Implementation of a regional branding program.

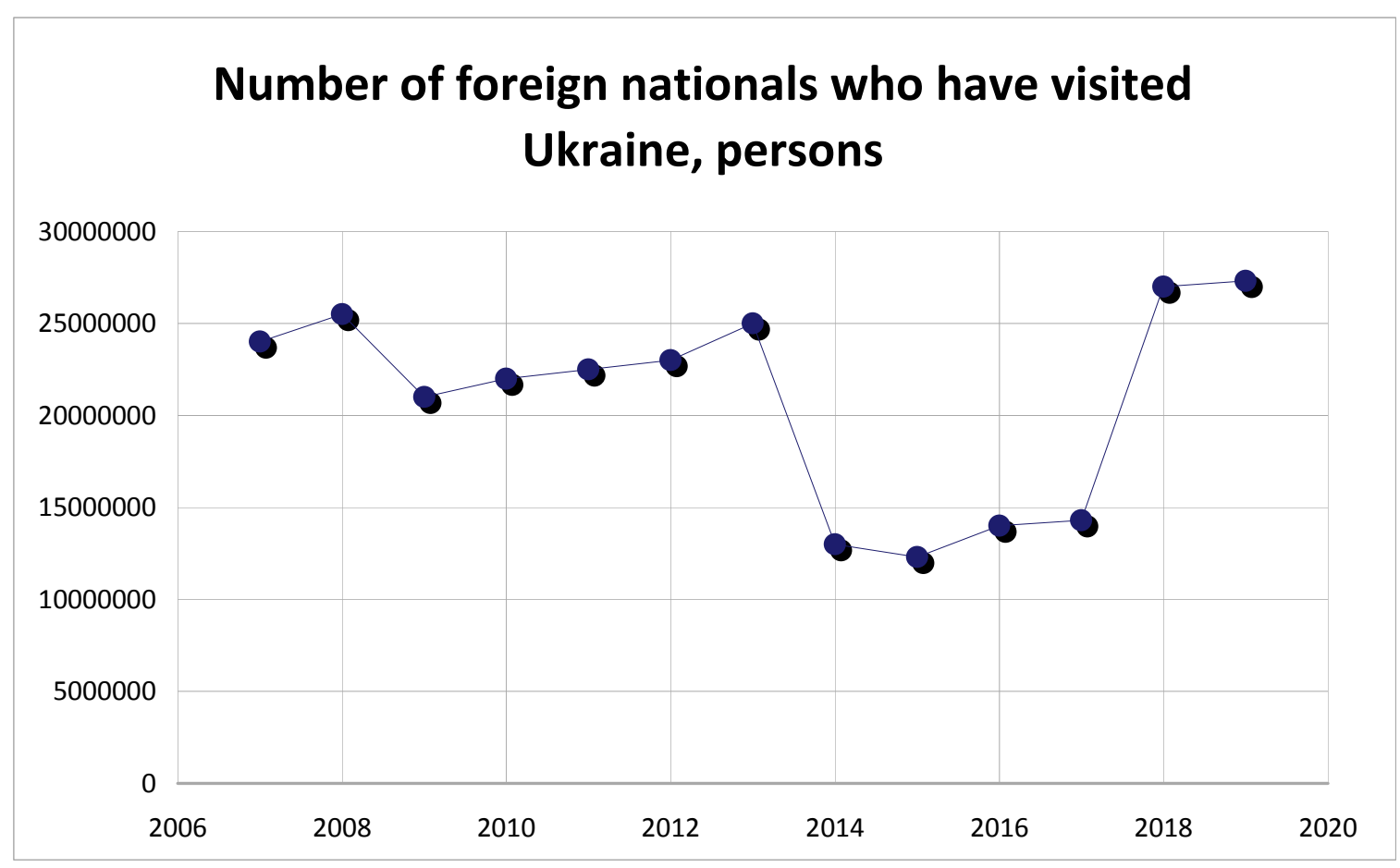

Fig. 2. Dynamics of the number of foreign visitors, 2007-2019

Sourse: https://www.me.gov.ua/?lang=uk-UA; http://ukrstat.gov.ua/; https://nv.ua/ukr/biz/economics/ stagnaciya-v-turizmi-kilkist-inozemciv-yaki-prijizhdzhayut-v-ukrajinu-za-rik-mayzhe-ne-zminilasya50068814.html

In the field of tourism, already in the late 1970s, the concepts of (tourist) destination (destination), and accordingly marketing of destinations and branding of destinations, arose. Destination branding and territorial branding have differences, as are the commercial branding tools used in these areas. So many researchers believe, including S. Anholt [2, p. 3].

The first difference between a destination and a territory can be called a geographical factor. [2, 3] A place is a country, region or city with clear administrative boundaries, while a destination is the purpose of a tourist's trip, which can also be cross-border in political and administratively.

Conclusions. Thus, at this stage of development, branding plays one of the leading roles in shaping the tourist attractiveness of the region. The prosperity of the territory largely depends on the degree of tourism development, while the branding of the region is an important factor in the formation of its attractive sides. Branding contributes to the positioning and promotion of the region in the tourist markets - both 
in Ukrainian and international. Competent branding, the main task of which is to create a positive image of the region, can lead to the desired result - positioning the territory at various levels and attracting potential tourists to the region, which will increase revenue from tourism enterprises, increase the number of new jobs, and additional financing in the economy of the region and, accordingly, improving the quality of life of the population.

Based on the results of the study, we can draw the following conclusions. The right approach to the creation of branding of tourist destinations of Ukraine can have significant results: improving the image, enhancing the tourist and investment attractiveness of the territories of Ukraine, awareness of the residents of these regions of the value of the region, increasing self-esteem, belief in the potential and future of the area. But in order to do this, work must be done with real actions to improve the investment climate, infrastructure and living standards of the population. A complex problem is seeing the development of the territorial area by its population and understanding its role in the process.

The most effective will be the brand that is based on the real characteristics and attractive features of the destination. The study shows that, compared to foreign cities, where most brands are artificially created, Ukrainian small cities have a great potential to create a brand in their territory that will emphasize its uniqueness and emphasize its benefits, encourage tourists to prefer it and return here next time. The branding strategy of Ukraine's tourist destinations, taking into account its potential, should be based on the needs and expectations of the tourist, and this will emphasize the unique features that will distinguish a place with its own brand from other territories.

\section{REFERENCES}

1. Abellán Miquel. (2017). Impressive advertising. Barcelona: Monsa.. - 144 p.

2. Anholt, S. (2014). Competitive identity: the new brand management for nations, cities and regions. Place of publication not identified: Palgrave Macmillan. p. $1-6$.

3. Hollis, N. (2010). The global brand: how to create and develop lasting brand value in the world market. New York: Palgrave Macmillan. $-272 \mathrm{c}$.

4. Beckwith G. (2018). Selling invisible. Guide to modern marketing services. Kiev: KK KSD. -192 p.

5. Kurban O. (2016). PR in marketing communications. Kiev: Condor. $-246 \mathrm{p}$.

6. Milashovskaya O. (2013) Problems and prospects of formation of branding of small cities of Ukraine / O Milashovskaya, T Il'to // Innovative Economics. № 6. P. 16-18. - Access mode: http://nbuv.gov.ua/UJRN/inek_2013_6_5.

7. Trukhimovich S. (2016). Advertising. Copywriter's notes. A practical guide. Kyiv : Kyievo-Mohylianska Akademiia. -148 p. 